Eleanor J. Reimer MD FRCPC, Carolyne J. Montgomery MD FRCPC, Joan C. Bevan MD FRCA, Pamela M. Merrick BSN, Derek Blackstock MB FFARCSI FRCPC, Vladan Popovic MD

\title{
Propofol anaesthesia reduces early post- operative emesis after paediatric strabismus surgery
}

Propofol anaesthesia may reduce postoperative emesis. The purpose of this study was to compare the incidence of emesis after propofol anaesthesia with and without nitrous oxide, compared with thiopentone and halothane anaesthesia, in hospital and up to $24 \mathrm{hr}$ postoperatively, in outpatient paediatric patients after strabismus surgery. Seventy-five ASA class I or II, unpremedicated patients, aged 2-12 yr were randomly assigned to one of three groups: Thiopentone, $6.0 \mathrm{mg} \cdot \mathrm{kg}^{-1}$ iv induction followed by halothane and $\mathrm{N}_{2} \mathrm{O} / \mathrm{O}_{2}$ for maintenance $(\mathrm{T} / \mathrm{H})$; propofol for induction, followed by propofol and oxygen for maintenance $\left(P / \mathrm{O}_{2}\right)$; and propofol for $i v$ induction, followed by propofol infusion and $\mathrm{N}_{2} \mathrm{O} / \mathrm{O}_{2}$ for maintenance $\left(\mathrm{P} / \mathrm{N}_{2} \mathrm{O}\right)$. All received vecuronium, controlled ventilation, and acetaminophen pr. Morphine was given as needed for postoperative analgesia. There were no differences in age, weight, number of eye muscles operated upon, duration of anaesthesia or surgery. The $\mathrm{P} / \mathrm{N}_{2} \mathrm{O}$ group $\left(255 \pm 80 \mu \mathrm{g} \cdot \mathrm{kg}^{-1} \cdot \mathrm{min}^{-1}\right)$ received less propofol than the $P / O_{2}$ group $\left(344 \pm 60 \mu \mathrm{g} \cdot \mathrm{kg}^{-1} \cdot \mathrm{min}^{-1}\right)(P$ $\leq 0.0001)$ and had shorter extubation $(P<0.001)$ and recovery $(P<0.01)$ times. Emesis in the hospital, in both the $\mathrm{P} / \mathrm{N}_{2} \mathrm{O}$ (4.0\%) and $\mathrm{P} / \mathrm{O}_{2}$ group (4.0\%) was less than in the $\mathrm{T} / \mathrm{H}$ group (32\%) $(P<0.01)$. Antiemetics were required in four patients in the $T / H$ group (16.0\%). Overall emesis afier surgery was not different among the groups: $\mathrm{T} / \mathrm{H}(48 \%), \mathrm{P} / \mathrm{O}_{2}(28 \%)$ and

\section{Key words}

ANAESTHESIA: outpatient, paediatric, ophthalmologic; ANAESTHETICS, GASES: nitrous oxide; ANAESTHETICS, INTRAVENOUS: propofol, thiopentone; ANAESTHETICS, VOLATILE: halothane; VOMITING: incidence.

From the Department of Anaesthesia, University of British Columbia and British Columbia's Children's Hospital, Vancouver, BC, Canada.

Address correspondence to: Dr. C.J. Montgomery, Department of Anaesthesia, British Columbia's Children's Hospital, 4480 Oak Street, Vancouver, British Columbia, Canada V6H 3V4.

Accepted for publication 18th June, 1993.
$\mathrm{P} / \mathrm{N}_{2} \mathrm{O}$ (42\%). The use of propofol anaesthesia with and without $\mathrm{N}_{2} \mathrm{O}$ decreased only early emesis. This supports the concept of a short-acting, specific antiemetic effect of propofol.

On attribue au propofol des propriété anti-émétiques postopératoires. Cette étude a pour objectif de comparer lincidence des vomissements après l'anesthésie au propofol avec ou sans protoxyde d'azote, comparativement à l'anesthésie au thiopentonehalothane. Cette étude est réalisée à lhôpital et jusqu'à 24 heures après l'opération chez des patients ambulatoires après chirurgie pour strabisme. Soixante-quinze patients ASA I et II, non prémédiqués, âgés de 2 a 12 ans sont assignés au hasard à un de trois groupes: induction au thiopentone, $6,0 \mathrm{mg} \cdot \mathrm{kg}^{-1}$ avec maintien à l'halothane- $\mathrm{N}_{2} \mathrm{O},(\mathrm{T} / \mathrm{H})$; induction avec maintien au propofol-oxygène $\left(\mathrm{P} / \mathrm{O}_{2}\right)$ et induction au propofol avec maintien au protoxyde-oxygène $\left(\mathrm{P} / \mathrm{N}_{2} \mathrm{O}\right)$. Tous reçoivent $d u$ vécuronium, une ventilation contrôlée et de l'acétaminophène rectal. De la morphine est administrée au besoin pour contrôler la douleur postopératoire. Il n'y a pas de différence d'âge, du poids, du nombre de muscles opérés et de durée anesthésique et chirurgicale. Les patients du groupe $\mathrm{P} / \mathrm{N}_{2} \mathrm{O}(255 \pm 80$ $\left.\mu \mathrm{g} \cdot \mathrm{kg}^{-1} \cdot \mathrm{min}^{-1}\right)$ reçoivent moins de propofol que le groupe $\mathrm{P} \mathrm{O}_{2}\left(344 \pm 60 \mu \mathrm{g} \cdot \mathrm{kg}^{-1} \cdot \mathrm{min}^{-1}, P<0,001\right)$, sont intubés moins longtemps $(P<0,0001)$ et s'eveillent plus rapidement $(P<0,01)$. A lhôpital, les vomissements dans les deux groupes $\mathrm{P} / \mathrm{N}_{2} \mathrm{O}(4,0 \%)$ et $\mathrm{P} / \mathrm{O}_{2}(4,0 \%)$ sont moins fréquents que dans le groupe $T / H(32 \%)$. Des antiémétiques sont requis chez quatre patients du groupe $\mathrm{T} / \mathrm{H}$ (16\%). Lincidence générale des vomissements après la chirurgie est la même pour tous les groupes: $\mathrm{T} / \mathrm{H}$ (48\%), $\mathrm{P} / \mathrm{O}_{2}(28 \%)$ et $\mathrm{P} / \mathrm{N}_{2} \mathrm{O}$ (42\%). Lutilisation du propofol en anesthésic avec ou sans $\mathrm{N}_{2} \mathrm{O}$ ne diminue que lincidence des vomissements précoces, ce qui supporte le concept d'une activité anti-émétique brève et spécifique.

Postoperative emesis accounts for one third of the postanaesthetic morbidity in paediatric patients, ${ }^{1}$ and vomiting is the most common reason for unanticipated admission to hospital in paediatric ambulatory surgical patients. $^{2}$ In children undergoing strabismus surgery, 
propofol anaesthesia has been reported to reduce the incidence of postoperative vomiting from $30-50 \%$ to 4-23\%. ${ }^{3,4}$ Despite the multifactorial origins of emesis, ${ }^{5}$ the wide variation in the frequency of reported vomiting in these studies may have resulted from the use of premedication, narcotics, nitrous oxide $\left(\mathrm{N}_{2} \mathrm{O}\right)$ and antiemetics.

This study examined the incidence of emesis after propofol anaesthesia with and without nitrous oxide, compared with thiopentone and halothane anaesthesia, in hospital and up to $24 \mathrm{hr}$ after surgery, in outpatient paediatric patients after strabismus surgery.

\section{Methods}

Following institutional approval and informed written, parental consent, 75 healthy children, ASA physical status I or II, aged 2-12 yr, scheduled for elective outpatient, strabismus surgery were studied. Patients were assigned to receive one of three anaesthetic regimens: thiopentone, $6.0 \mathrm{mg} \cdot \mathrm{kg}^{-1} i v$ induction followed by halothane $0.5-1.5 \%$ and nitrous oxide $70 \%$ /oxygen for maintenance $(\mathrm{T} / \mathrm{H})$; propofol, $5.0 \mathrm{mg} \cdot \mathrm{kg}^{-1} \dot{N}$ followed by propofol and oxygen $\left(\mathrm{P} / \mathrm{O}_{2}\right)$; and propofol, $5.0 \mathrm{mg} \cdot \mathrm{kg}^{-1} \dot{i}$ followed by propofol and nitrous oxide $70 \%$ / oxygen maintenance $(\mathrm{P} /$ $\mathrm{N}_{2} \mathrm{O}$ ).

Routine fasting instructions were followed, with solid foods allowed up to six hours and clear fluids allowed up to four hours preoperatively. Patients were unpremedicated. A local anaesthetic cream, EMLA ${ }^{\circledR}$, was applied to the dorsum of the hands one to two hours before surgery. Retrograde amnesia was tested in children greater than four years by showing a picture of an animal to the child 30-60 min before induction and testing for recall one to two hours after discontinuation of the anaesthetic.

At induction of anaesthesia, an intravenous infusion of Ringer's Lactate solution was commenced through a $22^{\circ}$ or $24^{\circ}$ cannula inserted on the dorsum of the hand. All patients received atropine, $0.02 \mathrm{mg} \cdot \mathrm{kg}^{-1} i \mathrm{iv}$ and lidocaine $0.3 \mathrm{mg} \cdot \mathrm{kg}^{-1} i v$ prior to the assigned induction agent. The induction was observed for the presence of largyngospasm, bradycardia, hypotension (BP $<20 \%$ of baseline), and pain on injection. Tracheal intubation was facilitated by muscle relaxation with vecuronium, 0.1 $\mathrm{mg} \cdot \mathrm{kg}^{-1} \dot{i}$.

Routine monitoring was established with a precordial stethoscope, ECG, oxygen saturation monitor, end-tidal carbon dioxide monitor, automated oscillometric blood pressure recorder, temperature probe and peripheral nerve stimulation. Rectal acetaminophen $15 \mathrm{mg} \cdot \mathrm{kg}^{-1}$ was given after induction. All patients received Ringer's Lactate, $10 \mathrm{ml} \cdot \mathrm{kg}^{-1}$ over one hour followed by maintenance fluid at a rate of $4.0 \mathrm{ml} \cdot \mathrm{kg}^{-1} \cdot \mathrm{hr}^{-1}$ for the first $10 \mathrm{~kg}$, an additional $2.0 \mathrm{ml} \cdot \mathrm{kg}^{-1} \cdot \mathrm{hr}^{-1}$ for body weight between 10 and $20 \mathrm{~kg}$ and an additional 1.0 $\mathrm{ml} \cdot \mathrm{kg}^{-1} \cdot \mathrm{hr}^{-1}$ for above $20 \mathrm{~kg}$.

Anaesthesia was maintained according to group randomization with controlled ventilation to maintain normocapnia $\left(\mathrm{PETCO}_{2} 35-40 \mathrm{mmHg}\right)$. Incremental doses of vecuronium $\left(0.025-0.05 \mathrm{mg} \cdot \mathrm{kg}^{-1} i v\right)$ were given to maintain surgical relaxation. In the propofol groups, an intravenous infusion of propofol was commenced at $300 \mu \mathrm{g} \cdot \mathrm{kg}^{-1} \cdot \mathrm{min}^{-1}$ and then titrated $(150-400$ $\left.\mu \mathrm{g} \cdot \mathrm{kg}^{-1} \cdot \min ^{-1}\right)$ as needed to maintain clinically satisfactory anaesthesia. Halothane or propofol were discontinued at the time of the last conjunctival manipulation. Nitrous oxide was continued in the $\mathrm{T} / \mathrm{H}$ and $\mathrm{P} / \mathrm{N}_{2} \mathrm{O}$ groups until residual neuromuscular blockade was reversed with edrophonium $0.5 \mathrm{mg} \cdot \mathrm{kg}^{-1}$ and atropine 0.01 $\mathrm{mg} \cdot \mathrm{kg}^{-1}$. The trachea was extubated when the patient was swallowing and making purposeful movements such as reaching up for the endotracheal tube.

All patients were observed for two hours after discontinuation of the anaesthetic by recovery room nursing staff who followed the usual protocols including offering clear fluids or frozen fluids (Popsicles $\left.{ }^{(}\right)$to the patients. Morphine $50 \mu \mathrm{g} \cdot \mathrm{kg}^{-1} i \mathrm{v}$ up to three doses, was given as needed at the nurse's discretion.

Postoperative antiemetic therapy was given after the second emesis with metoclopramide $0.15 \mathrm{mg} \cdot \mathrm{kg}^{-1}$ iv. After a third episode of emesis and at least $15 \mathrm{~min}$ after the first antiemetic, dimenhydrinate $0.5 \mathrm{mg} \cdot \mathrm{kg}^{-1} i v$ was given.

At discharge, patients over four years were asked if they could recall the picture shown preoperatively. Parents were instructed to give their children oral acetaminophen $10 \mathrm{mg} \cdot \mathrm{kg}^{-1}$ and codeine $1.0 \mathrm{mg} \cdot \mathrm{kg}^{-1}$ for analgesia if necessary and also to give dimenhydrinate 1.0 $\mathrm{mg} \cdot \mathrm{kg}^{-1}$ orally or rectally if necessary for excessive emesis after discharge from hospital. The parents were telephoned the day after surgery to ascertain if their child had vomited. Parents and the patient were not informed of the anaesthetic technique until the conclusion of the telephone interview.

\section{Data collected}

The age, weight and sex of the patients were recorded. The type of surgery, (i.e., recession, resection myectomy), number of eye muscles operated upon, and whether the surgery was unilateral or bilateral was recorded. The anaesthetic time was calculated from the time of intravenous induction to discontinuation of the nitrous oxide (T/H and $\left.\mathrm{P} / \mathrm{N}_{2} \mathrm{O}\right)$ or propofol infusion $\left(\mathrm{P} / \mathrm{O}_{2}\right)$. The surgical time was measured from the time of the first conjunctival incision until the last conjunctival manipulation. The time to extubation was measured from the time of discontin- 
TABLE I Demographic data

\begin{tabular}{lllll}
\hline Parameter & Thio/ Hal & PropofollO & Propofol/ $\mathrm{N}_{2} \mathrm{O}$ & P value \\
\hline Number of patients* & 25 & 25 & 25 & \\
Age (yr) $\dagger$ & $6.2 \pm 2.2$ & $6.3 \pm 1.9$ & $5.1 \pm 2.5$ & 0.11 \\
Weight $(\mathrm{kg}) \ddagger$ & $21.1(11-42)$ & $20(14-50)$ & $18(10-47)$ & 0.18 \\
Sex (M/F)* & $7 / 18$ & $11 / 14$ & $9 / 16$ & 0.5 \\
Eyes $(1 / 2)^{*}$ & $4 / 21$ & $8 / 17$ & $8 / 17$ & 0.34 \\
\hline
\end{tabular}

Thio $=$ thiopentone $\mathrm{Hal}=$ halothane.

*Count.

$\dagger$ Mean \pm SD

$\ddagger$ Median (range).

uation of anaesthetic agents (end anaesthesia) to the time of tracheal extubation.

In the recovery room, recovery and emesis were observed by trained, recovery room nursing staff who were blinded to the group assignment. Recovery time was measured using the Steward ${ }^{6}$ recovery score at fiveminute intervals until the maximum score of six was obtained. The time from arrival in the post-anaesthetic recovery room (PACU) until a score of six was achieved was recorded as the recovery time. The eye opening time was measured as the time from extubation to the time of first eye opening in response to voice command.

A modified Abramowitz ${ }^{7}$ emesis score was performed at $15 \mathrm{~min}$ intervals $(0=$ none, $1=$ mild, once in a 15 min period; $2=$ moderate, two or three times in a 15 min period; $3=$ severe, four or more times in a $15 \mathrm{~min}$ period; $4=$ persistent and severe emesis despite treatment with metoclopramide or dimenhydrinate). Involuntary retching was scored as emesis but nausea was not evaluated.

The length of stay in the PACU and the day care unit (DCU) were recorded. These times were added to give a duration of hospital stay. The time to oral intake was measured from the time of discontinuation of the anaesthetic to the time of first oral intake. Morphine utilization was measured by recording the number and the time of administration. The time to first morphine administration was measured from the time of discontinuation of the anaesthetic. Any antiemetic administration was also recorded.

Emesis after discharge from hospital was recorded by telephone interview for the following intervals; during transport home, during the first $12 \mathrm{hr}$ after discharge, and during the second $12 \mathrm{hr}$ after discharge. Overall emesis was defined as the total incidence of emesis at any of the study intervals.

\section{Data analyses}

Sample size calculation was based on a power analysis, using values of $\alpha=0.05$ and $\beta=0.2$. An $80 \%$ incidence of emesis was predicted in the $\mathrm{T} / \mathrm{H}$ group and a $50 \%$ reduction in the incidence of emesis expected in the propofol groups. The sample size required was 23 subjects per treatment. Normally distributed data were summarized using means and standard deviations. Skewed data were expressed as medians and ranges. Categorical data were expressed as counts. Continuous variables that were normally distributed were analyzed by one-way analysis of variance with Newman-Keuls test for multiple comparisons and skewed continuous data were analyzed with the Kruskal-Wallis test using Dunn's test for multiple comparisons.

Categorical data were analyzed with Chi-square test or Fisher's exact test when expected frequencies were $<5$. Bonferroni's correction was used for multiple intergroup comparisons in contingency tables. The mean doses of propofol in the propofol groups were compared using an unpaired $t$ test. A $P$ value of $<0.05$ was considered significant.

\section{Results}

Seventy-five patients were enrolled in the study, 25 in each group. Complete data were obtained with the following exceptions. Discharge was delayed for surgical reasons in one patient in the $\mathrm{P} / \mathrm{N}_{2} \mathrm{O}$ group. Recovery data relating to times of discharge and emesis data after discharge in this patient were excluded from analysis. Four patients, two in the $\mathrm{T} / \mathrm{H}$ group and one in each of the propofol groups were discharged before two hours postoperatively, at 100-119 $\mathrm{min}$. These data are included.

There were no differences among the three groups with regard to age, weight, sex, number of eye muscles repaired or number of eyes operated upon (Table I). Most surgical procedures were bilateral, two muscle repairs involved a combination of recessions and resections (Figure 1). There were a total of twenty different surgical procedure categories performed by five different surgeons.

Intravenous cannulation on the dorsum of the hand was achieved in all patients. The incidence of pain on injection of propofol was $18.4 \%$. No bradycardia, hypotension or laryngospasm was observed during induction. 
TABLE II Anaesthetic, surgery, and recovery times

\begin{tabular}{|c|c|c|c|c|}
\hline Parameters & Thio/Hal & Propofol/ $\mathrm{O}_{2}$ & Propofol/ $\mathrm{N}_{2} \mathrm{O}$ & $P$ value \\
\hline Duration of surgery $\dagger$ & $32 \pm 13$ & $29 \pm 9$ & $29 \pm 9$ & 0.52 \\
\hline Duration of anaesthesia $\dagger$ & $44 \pm 13$ & $40 \pm 10$ & $41 \pm 10$ & 0.50 \\
\hline Time to extubation $\dagger$ & $10 \pm 5$ & $11 \pm 5$ & $6 \pm 3$ & $0.0005^{*}$ \\
\hline Time to eye openingt & $32(10-51)$ & $26(12-99)$ & $14(3-59)$ & $0.000 \mathrm{I}^{*}$ \\
\hline Time to recovery score of $6 \dagger$ & $36 \pm 12$ & $33 \pm 11$ & $24 \pm 13$ & $0.0037^{*}$ \\
\hline Time to first oral intakef & $69(28-153)$ & $72(24-154)$ & $58(31-138)$ & 0.43 \\
\hline Duration of PACU stay ${ }^{\dagger}$ & $65 \pm 23$ & $70 \pm 21$ & $64 \pm 16 \S$ & 0.52 \\
\hline Duration of DCU staył & $85(50-180)$ & $85(20-164)$ & $79(54-180) \S$ & 0.63 \\
\hline Duration of hospital stayf & $155(102-260)$ & $148(118-230)$ & $140(100-236) \S$ & 0.35 \\
\hline
\end{tabular}

Thio $=$ thiopentone $\mathrm{Hal}=$ halothane.

$* P<0.05$, propofol $/ \mathrm{N}_{2} \mathrm{O}$ vs thio/hal and propofol $/ \mathrm{N}_{2} \mathrm{O}$ vs propofol $/ \mathrm{O}_{2}$.

†Mean \pm SD.

$\ddagger$ Median (range).

$\S N=24$.

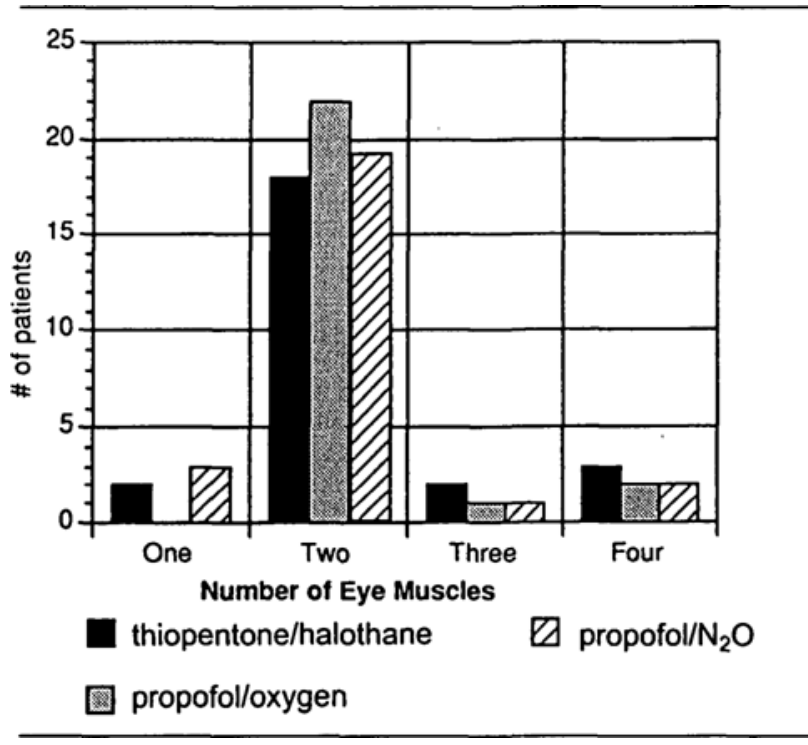

FIGURE I Number of eye muscles operated upon.

The $\mathrm{P} / \mathrm{N}_{2} \mathrm{O}$ group received a lower dose (mean $\pm \mathrm{SD}$ ) of propofol than the $\mathrm{P} / \mathrm{O}_{2}$ group $(255 \pm 80$ vs $344 \pm$ $\left.60 \mu \mathrm{g} \cdot \mathrm{kg}^{-1} \cdot \min ^{-1}\right)(P=0.0001)$. The durations of surgery and anaesthesia and the stay in the PACU and DCU were similar among the three groups. The time from discontinuation of the anaesthetic to first oral intake was also similar. The $\mathrm{P} / \mathrm{N}_{2} \mathrm{O}$ group had a shorter time to extubation, recovery time, and time to first eye opening than the $\mathrm{T} / \mathrm{H}$ and $\mathrm{P} / \mathrm{O}_{2}$ groups (Table II).

The number of patients who received morphine for analgesia was the same in each group. However, patients in the $\mathrm{P} / \mathrm{N}_{2} \mathrm{O}$ group received morphine earlier during the recovery period (Table IV).

Emesis in the hospital occurred in eight patients (32\%) in the $\mathrm{T} / \mathrm{H}$ group and in one patient in each of the propofol groups (4\%). Patients who vomited in hospital con-

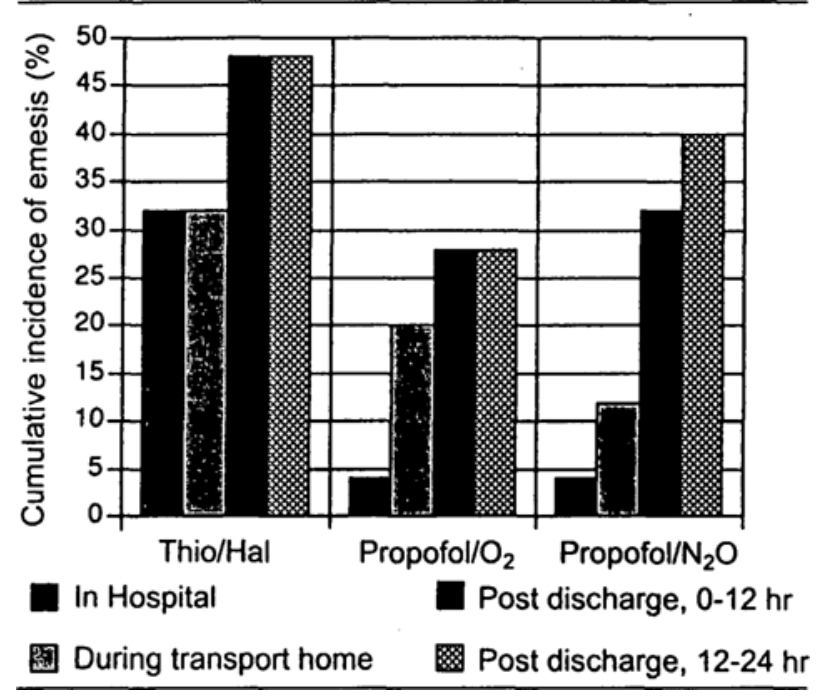

FIGURE 2 The cumulative incidence of postoperative emesis.

tinued to have further episodes after discharge. Additional patients in all of the groups vomited during the car ride home and, after discharge, nearly half of the patients vomited during the first $12 \mathrm{hr}$ after discharge, with no difference among the three groups (Table III). When overall emesis in the groups during the $24 \mathrm{hr}$ study period was compared, no differences in the incidence of emesis were found; $\mathrm{T} / \mathrm{H}, 48 \%, \mathrm{P} / \mathrm{O}_{2}, 28 \%$, and $\mathrm{P} / \mathrm{N}_{2} \mathrm{O}, 42 \%$ (Figure 2).

Metoclopramide, was administered to four patients in the $\mathrm{T} / \mathrm{H}$ group but no patients in the propofol groups required any antiemetic while in hospital (Table III). No patient vomited more than twice while in the hospital.

Picture recall was tested in $\mathbf{4 8}$ patients and was positive and similar in all groups, $\mathrm{T} / \mathrm{H}, 16 / 17$ patients, (94\%), $\mathrm{P} / \mathrm{O}_{2}, 18 / 19$ patients $(95 \%)$, and $\mathrm{P} / \mathrm{N}_{2} \mathrm{O}, 11 / 12$ patients (92\%). No intraoperative awareness was reported. 
TABLE III The incidence and time of postoperative emesis and antiemetic use

\begin{tabular}{lllll}
\hline Time of postoperative emesis & Thio/ Hal & Propofol/O & Propofol/ $\mathrm{N}_{2} \mathrm{O}$ & P value \\
\hline In hospital $\dagger$ & $8(32)$ & $1(4)$ & $1(4)$ & $0.0017^{*}$ \\
During transport home $\dagger$ & $2(8)$ & $4(16)$ & $2(8) \ddagger$ & 0.71 \\
Post-discharge, 0 to $\leq 12 \mathrm{hr} \dagger$ & $9(36)$ & $6(24)$ & $8(33) \ddagger$ & 0.63 \\
Post-discharge, $>12$ to $24 \mathrm{hr} \dagger$ & $3(12)$ & $1(4)$ & $5(21) \ddagger$ & 1.0 \\
Cumulative emesis $\dagger$ & $12(48)$ & $7(28)$ & $10(42) \ddagger$ & 0.34 \\
Metoclopramide received $\dagger$ & $4(16)$ & $0(0)$ & $0(0)$ & 0.11 \\
\hline
\end{tabular}

Thio $=$ thiopentone $\mathrm{Hal}=$ halothane.

* $P<0.0166$, propofol $/ \mathrm{N}_{2} \mathrm{O}$ vs thio/hal and propofol $/ \mathrm{O}_{2}$ vs thio $/$ hal.

†incidence (\%).

tn $=24$.

TABLE IV Morphine administration after surgery

\begin{tabular}{lllll}
\hline Morphine administration & Thio/Hal & Propofol/ $\mathrm{O}_{2}$ & Propofol/ $\mathrm{N}_{2} \mathrm{O}$ & P value \\
\hline \# of patients given morphine & $13(52)$ & $17(68)$ & $21(84)$ & 0.053 \\
\# of morphine doses $(1 / 2 / 3) \ddagger$ & $8 / 5 / 0$ & $6 / 9 / 2$ & $5 / 14 / 2$ & 0.085 \\
Time of Ist. dose (mins) $\dagger$ & $42(19-93)$ & $31(14-74)$ & $19(12-52)$ & $0.004^{*}$ \\
\hline
\end{tabular}

Thio $=$ thiopentone $\mathrm{Hal}=$ halothane.

" $P<0.05$, propofol $/ \mathrm{N}_{2} \mathrm{O}$ vs thio/ hal and propofol $/ \mathrm{N}_{2} \mathrm{O}$ vs prop $/ \mathrm{O}_{2}$.

$\dagger$ Median (range).

tCount (\%).

Post hoc analysis of the data showed that patients who vomited in hospital during the first $12 \mathrm{hr}$ after discharge or who had vomited at any time had had longer mean anaesthetic times than patients who did not. Vomiting could not be correlated to narcotic use. Vomiting occurred in $56 \%$ of patients $\leq 3 \mathrm{yr}$ and in $59 \%$ of patients $\leq 4$ yr (NS).

\section{Discussion}

This study confirms that the use of propofol anaesthesia decreases the incidence and severity of early postoperative emesis in children after strabismus surgery. Propofol, regardless of whether nitrous oxide was part of the anaesthetic technique, reduced emesis in hospital to $4 \%$ compared with $32 \%$ when thiopentone, halothane and nitrous oxide were used. However, after discharge from hospital, $28-40 \%$ of all children vomited despite which anaesthetic was given. The highest incidence of vomiting occurred in the first $12 \mathrm{hr}$ after discharge.

When propofol was used with nitrous oxide, a lower total dose of propofol was given. Extubation was achieved five minutes earlier and recovery occurred nine minutes sooner. All patients left the hospital within three hours. Morphine was given earlier to patients who had received propofol and nitrous oxide. Very few patients required antiemetics in hospital and these were confined to those who had received thiopentone and halothane.
These results are similar to those of Watcha ${ }^{3}$ who found a $50 \%$ incidence of vomiting after $24 \mathrm{hr}$ after halothane anaesthesia. This was reduced to $23 \%$ following propofol and air. When nitrous oxide was used with propofol, the incidence was $60 \%$. Larsson, studying the same time period, documented a lower incidence of $27 \%$ after thiopentone and halothane and an incidence of $5 \%$ when propofol and nitrous oxide were used. ${ }^{4}$

A number of factors may have led to the wide variation in the reported incidence of postoperative emesis in these similar studies. Rectal midazolam premedication and intravenous fentanyl at induction were given in the Larsson study. Patients had compulsory gastric drainage intraoperatively and were allowed to refuse oral intake postoperatively. ${ }^{4}$ Droperidol was used prophylactically in the halothane group in the Watcha study and patients underwent inhalational induction prior to receiving intravenous propofol. Morphine was also given at induction. ${ }^{3}$ Patients in our study received no premedication and all underwent an intravenous induction. No narcotics or antiemetics were given until the postoperative period.

The mechanism of the antiemetic effect of propofol is speculative. These three studies show that, despite less postoperative sedation and the use of perioperative narcotics, the use of propofol decreases the incidence of emesis before discharge from hospital. This antiemetic effect does not protect against the factors that cause vomiting 
after discharge, (e.g., ambulation, subsequent alimentation or pain). Propofol, after a single dose of $2.5 \mathrm{mg} \cdot \mathrm{kg}^{-1}$ in children, has a three-compartment elimination profile, with a rapid clearance exceeding hepatic blood flow resulting in a $T_{1 / 2 \beta}$ of $9 \mathrm{~min}$ and a $T_{1 / 2 \mathrm{~g}}$ of $215 \mathrm{~min}{ }^{8}$ It may be that the drug is cleared so rapidly that the propofol is no longer present in a high enough concentration in antiemetic centres while emetic stimuli such as an oculovestibular reflex remain active. Whether propofol is still effective in reducing vomiting when used for induction alone and not for the maintenance of anaesthesia remains to be seen.

The doses of propofol used in this study for induction and maintenance are higher than those previously reported. ${ }^{8-11}$ In two of these studies, 9,11 intravenous induction doses were determined using mask acceptance as an end-point and, after loss of consciousness, mask ventilation with halothane and nitrous oxide was commenced. In Borgeat's study, ${ }^{10}$ propofol $3.0 \mathrm{mg} \cdot \mathrm{kg}^{-1}$ was used for induction without the concurrent use of premedication, narcotics or potent inhalational agents and the incidence of "spontaneous movement" during induction was $75 \%$. This was reduced to $14 \%$ in a subsequent study when propofol $5.0 \mathrm{mg} \cdot \mathrm{kg}^{-1}$ was used. ${ }^{12}$ After a pre-trial clinical assessment, we found that a lower induction dose of $3.5 \mathrm{mg} \cdot \mathrm{kg}^{-1}$ despite the immediate commencement of a maintenance infusion of $300-400$ $\mu \mathrm{g} \cdot \mathrm{kg}^{-1} \cdot \mathrm{min}^{-1}$ was inadequate to maintain suitable clinical conditions for mask ventilation, particularly when nitrous oxide was not used. We found no adverse effects with the use of propofol $5.0 \mathrm{mg} \cdot \mathrm{kg}^{-1}$ for induction. The use of fentanyl or morphine at induction decreases the amount of propofol needed. 3,4

The effect of nitrous oxide on vomiting remains controversial. After the first postoperative day, the incidence of vomiting in the propofol/oxygen versus the propofol/ $\mathrm{N}_{2} \mathrm{O}$, group ( $28 \%$ and $42 \%$ respectively), was not different. Given the observed incidence of vomiting of $48 \%$ in the thiopentone/halothane group, the chance of Type II error in our study is $70 \%$, which is higher than expected. Despite the use of nitrous oxide in Larsson's study, ${ }^{4}$ the incidence of vomiting in the propofol group was only $5 \%$. Watcha, ${ }^{3}$ however, found a higher incidence of vomiting when nitrous oxide was used with propofol compared to propofol alone (60\% and $23 \%$ respectively). These differences may be explained in part by the differences in study design. The disadvantages of the use of propofol alone are the use of a higher maintenance dose, $17 \%$ to $35 \%$, a somewhat prolonged awakening time and the possibility of intraoperative awareness. $3,4,13$

Opioids, either fentanyl or morphine, were used in this and other cited studies. ${ }^{3,4}$ The use of morphine postoperatively did not increase the incidence of vomiting imme- diately postoperatively or after discharge. It is uncertain why the recovery room nursing staff gave more morphine to patients who had received propofol and nitrous oxide. While the children may have been experiencing more pain than the other groups, no pain scoring system was used to substantiate this and it is possible that morphine was used to treat agitation, especially in the younger children where pain is more difficult to assess and the psychological effects of separation from parents are greater. Larsson's study also described more frequent agitation in the propofol-fentanyl group. ${ }^{4}$

The effect of lidocaine given at induction prior to strabismus surgery is controversial. Werner reported a decrease in the incidence of postoperative vomiting from $52 \%$ to $16 \%$ after lidocaine $1.0 \mathrm{mg} \cdot \mathrm{kg}^{-1}$, but Christensen reported an incidence of $50 \%$ after lidocaine 1.5 $\mathrm{mg} \cdot \mathrm{kg}^{-1}$. 14,15 Lidocaine $0.2 \mathrm{mg} \cdot \mathrm{kg}^{-1}$ combined with propofol $3.0 \mathrm{mg} \cdot \mathrm{kg}^{-1}$ decreases the incidence of pain on injection in paediatric patients. ${ }^{16}$ Because of a potential antiemetic effect of lidocaine, our study was designed so that patients in all groups received lidocaine. The incidence of pain on injection in this study using lidocaine, $0.3 \mathrm{mg} \cdot \mathrm{kg}^{-1}$ mixed with propofol $5.0 \mathrm{mg} \cdot \mathrm{kg}^{-1}$, was $18 \%$. When this higher dose of propofol is used, a higher dose of lidocaine may be required to prevent injection pain.

With respect to the effect of the surgical procedure on vomiting, the initial hypothesis was that recession causes more traction on eye muscle spindles than resection and may cause more postoperative pain and vomiting. In this study, $49 \%$ of the procedures were bilateral medial or lateral recession; only $8 \%$ of procedures were bilateral resections. The remaining operations were a variety of combinations of recessions, resections and myectomies so this relationship was not examined further.

In conclusion, the use of propofol for induction and maintenance of anaesthesia in paediatric patients undergoing strabismus surgery is effective as it almost eliminates postoperative vomiting in hospital. Whether propofol reduces vomiting after discharge requires further study with a larger number of patients.

\section{Acknowledgements}

The authors gratefully acknowledge the assistance and encouragement of Dr. Clayton Reichert, the nursing staff of the DCU, OR and PAR and the surgeons of the Ophthalmology Department at BCCH.

\section{References}

1 Cohen MM, Cameron CB, Duncan PG. Pediatric anesthesia morbidity and mortality in the perioperative period. Anesth Analg 1990; 70: 160-7.

2 Patel RI, Hannallah RS. Anesthetic complications follow- 
ing pediatric ambulatory surgery: a 3-yr study. Anesthesiology 1988; 69: 1009-12.

3 Watcha MF, Simeon RM, White PF, Stevens JL. Effect of propofol on the incidence of postoperative vomiting after strabismus surgery in pediatric outpatients. Anesthesiology 1991; 75: 204-9.

4 Larsson S, Asgeirsson B, Magnusson J. Propofol-fentanyl anesthesia compared to thiopenal-halothane with special reference to recovery and vomiting after pediatric strabismus surgery. Acta Anaesthesiol Scand 1992; 36: 182-6.

5 Watcha MF, White $P F$. Postoperative nausea and vomiting. Its etiology, treatment, and prevention. Anesthesiology 1992; 77: 162-84.

6 Steward DJ. A simplified scoring system for the postoperative recovery room. Can Anaesth Soc J 1975; 22: 111-3.

7 Abramowitz MD, Oh TH, Epstein BS, Ruttimann UE, Friendly DS. The antiemetic effect of droperidol following outpatient strabismus surgery in children. Anesthesiology, 1983; 59: 579-83.

8 Valionen M, Iisalo E, Kanto J, Rosenberg P. Propofol as an induction agent in children: pain on injection and pharmacokinetics. Acta Anaesthesiol Scand 1989; 33: 152-5.

9 Morton NS, Wee M, Christie G, Gray IG, Grant IS. Propofol for induction of anaesthesia in children. A comparison with thiopentone and halothane inhalational induction. Anaesthesia 1988; 43: 350-5.

10 Borgeat A, Popovic V, Meier D, Schwander D. Comparison of propofol and thiopental/halothane for short-duration ENT surgical procedures in children. Anesth Analg 1990; 71: 511-5.

11 Hannallah RS, Baker SB, Casey W, McGill WA, Broadman $L M$, Norden JM. Propofol: effective dose and induction characteristics in unpremedicated children. Anesthesiology 1991; 74: 217-9.

12 Borgeat A, Dessibourg C, Popovic V, Meier D, Blanchard $M$, Schwander $D$. Propofol and spontaneous movements: an EEG study. Anesthesiology 1991; 74: 24-7.

13 Kelly JS, Roy RC. Intraoperative awareness with propofoloxygen total intravenous anesthesia for microlaryngeal surgery. Anesthesiology 1992; 77: 207-9.

14 Warner LO, Rogers GL, Martino JD, Bremer DL, Beach $T P$. Intravenous lidocaine reduces the incidence of vomiting in children after surgery to correct strabismus. Anesthesiology 1988; 68: 618-21.

15 Christensen S, Farrow-Gillespie A, Lerman J. Incidence of emesis and postanesthetic recovery after strabismus surgery in children: a comparison of droperidol and lidocaine. Anesthesiology 1989; 70: 251-4.

16 Cameron E, Johnston G, Crofts $S$, Morton NS. The minimum effective dose of lignocaine to prevent injection pain due to propofol in children. Anaesthesia 1992; 47: 604-6. 